\title{
ОПТИМІЗАЦІЯ ЗАСОБІВ НАВЧАННЯ, КОНТРОЛЮ ТА САМОКОНТРОЛЮ РІВНЯ ЗАСВОСННЯ ЗНАНЬ СТУДЕНТІВ- МЕДИКІВ
}

\author{
О. Ю. Руда, О. В. Костильов \\ Начіональний медичний університет імені О. О. Богомольияя
}

\section{OPTIMIZATION OF THE MEANS OF TRAINING, CONTROL AND SELF- CONTROL OF KNOWLEDGE MASTERING LEVEL OF MEDICAL STUDENTS}

\author{
O. Yu. Ruda, O. V. Kostylov \\ National Medical University by O. O. Bohomolets
}

\begin{abstract}
У статті описані підходи для розробки професійно-оріснтованого комплексу тестових завдань для їх використання студентами медичних вузів при вивченні навчальної дисципліни “Медична біологія".
\end{abstract}

The conceptional ways of development of professionally-oriented test tasks complex for medical students' use during mastering the science "Medical Biology" are described in the article.

Вступ. Удосконалення засобів навчання для використання студентами у процесі фахової підготовки $\epsilon$ однією з актуальних проблем сучасної освіти. Основною метою їх використання у педагогічній діяльності $€$ поліпшення вивчення та засвоєння навчального матеріалу студентами, зокрема вищих медичних навчальних закладів IV рівня акредитації. Медична біологія є однією з перших дисциплін, що вивчається у вищих медичних закладах освіти, в процесі засвоєння якої першокурсник орієнтується на базові вимоги до себе як до студента-медика $[1,2]$. Використання тестових завдань студентом на першому році навчання у вищому медичному закладі освіти, зокрема у аудиторній і самостійній позааудиторній роботі, може сприяти соціально-психологічній та професійній адаптації студента, формуванню навичок, які студент зможе застосовувати у засвоєнні знань не лише 3 предметів природничо-наукового спрямування, але й при вивченні професійно-орієнтованих дисциплін на старших курсах.

Основна частина. Розробляючи принципи створення професійно-орієнтованих тестових завдань, ми виходили із загальнодидактичних положень методики викладання медичної біології як навчальної дисципліни та звернули увагу на нерозривно пов' язані між собою складові: зміст навчання, діяльність викладача, студентів та час, який вони можуть використати на підготовку. Задля дослідження закономірностей між цими сторонами навчального процесу ми вивчили зміст навчальної дисципліни; проаналізували історичний аспект методики формування тестових завдань та пізнавальне і виховне значення завдань для створення професійно-орієнтованих тестових завдань, їх місця у навчально-виховному процесі вищих медичних навчальних закладів.

Присвоєння кваліфікації студенту-медику відбувається відповідно до вимог Галузевих стандартів вищої освіти. Згідно з ними проводяться стандартизовані тестові та практично-орієнтовані державні іспити. Адаптація особистості до таких вимог краще відбувається в процесі формування нових якостей, вмінь та навичок, які дозволяють успішно діяти в нових умовах. Одним 3 дієвих факторів стає робота 3 тестовими завданнями як засобами навчання, зокрема в аудиторній та самостійній позааудиторній роботі [3]. Тестові завдання містять інформацію про необхідні для засвоєння студентом знання, тому що орієнтовані на чітко визначений перелік питань, складений на базі навчальної програми, що сприятиме досягненню максимального результату ії засвоєння. Тому впровадження у навчальний процес тестових завдань різної структури та різного рівня складності зробить більш гнучким спосіб досягнення оптимального кінцевого результату навчання - фахової глибини і якості знань

() О. Ю. Руда, О. В. Костильов 
студентів, а включення тестових завдань у навчальну книгу сприятиме реалізації дидактичних функцій компенсаторності, адаптивності та інтегративності.

Професійно-орієнтовані тестові завдання можуть бути різної складності, що дозволяє проконтролювати якість знань на різних рівнях їх засвоєння: 1) $з$ однією правильною відповіддю, оскільки вони потребують менше часу на їхнє розв'язання й висвітлюють репродуктивний зріз знань; 2) на вибір відповіді, тому що вони спрямовані на розпізнавання об'єктів вивчення, закріплення інформації та можуть перевіряти знання термінів, окремих фактів; 3) на вибір з кількох тверджень, які добре підходять для з' ясування рівня засвоєння знань студентами, дають їм змогу відповісти на відносну велику кількість запитань протягом певного проміжку часу, що відводиться на тестування тощо; 4) на впізнавання можуть сприяти розвитку зорової пам'яті та асоціативного мислення в набутті навичок розпізнавання діагностично важливих об'єктів, зокрема морфології збудників інвазійних хвороб на різних стадіях онтогенезу, що часто буває основним у прийнятті остаточного рішення про їх наявність в організмі пацієнта; 5) на встановлення правильної послідовності, оскільки розпізнавання окремих стадій розвитку збудників інвазійних хвороб $\epsilon$ важливим для остаточної діагностики, розробки засобів профілактики, вибору форм і засобів лікування; 6) на встановлення відповідності легко складати, при цьому запитанням надають компактну та дієву форму, хоча вони переважно обмежуються оцінкою рівня знань, які базуються на асоціаціях, проте їх доречно використовувати, коли необхідно швидко і стисло оц-

\section{Література}

1. Костильов О. В. Створення моделі педагогічного тестування для оцінки рівня засвоєння знань при вивченні екології студентами-медиками / О. В. Костильов, О. Ю. Руда, О. В. Романенко // Вища освіта України. - 2010. - Дод. 4, т. III (21). - Тематичний випуск "Вища освіта України в контексті інтеграції до європейського освітнього простору”. C. $295-301$

2. Костильов О. В. Удосконалення методів навчання сту- інити рівень засвоєння знань студентом; 7) на встановлення причинно-наслідкових відношень можуть сприяти формуванню фахових компетентностей, що неможливо без чіткого усвідомлення ймовірних причин захворювання та його наслідків, при цьому йдеться про шляхи проникнення збудників хвороб в організм людини, алгоритми досягнення патологічних станів під дією певних чинників навколишнього середовища, а також тривалість хвороби, локалізацію паразитів, їх міграцію в організмі людини і можливі наслідки цих явищ; 8) на перевірку вміння застосовувати засвоєні знання, тобто завдання на інтерпретацію, вимагають від студентів продемонструвати не лише розуміння отриманої інформації, але й ії застосування в конкретних ситуаціях, тому вони включають інтерпретацію фактів, понять, принципів, правил, методів і теорій, їх легко адаптувати до всіх предметних напрямків; 9) на порівняння біологічних параметрів, оскільки їх знання є важливим компонентом потрібних майбутньому лікареві біологічних знань, які стають у нагоді при аналізі ризиків зараження людини відповідною хворобою, розробці профілактичних заходів у боротьбі з природно-вогнищевими і трансмісивними захворюваннями.

Висновок. Забезпечення студентів комплексом тестових завдань 3 тих розділів медичної біології, що вивчаються у вищому медичному закладі освіти, $є$ особливо актуальним завданням сьогодення, а використання тестових завдань студентом на першому році навчання, зокрема у аудиторній і самостійній позааудиторній роботі, сприятиме соціально-психологічній та професійній адаптації студента.

дентів у вищих медичних закладах освіти шляхом створення критеріально орієнтованих тестових завдань / О. В. Костильов, О. Ю. Руда, О. В. Романенко // Медична освіта. 2009. - № 2. - С. 92-94.

3. Гронлунд Н. Е. Оцінювання студентської успішності : практ. посіб. / Н. Е. Гронлунд. - К. : Навчально-методичний центр "Консорціум із удосконалення менеджмент-освіти в Україні”, 2005.-312 с. 